\title{
Povezanost lucidnih snova, obrambenih mehanizama i psihičkih tegoba
}

\section{/The Relationship Between Lucid Dreams, Defense Mechanisms and Mental Difficulties}

\author{
Marija Ivanović1, Nataša Šimić ${ }^{2}$
}

'Osnovna škola Julija Kempfa Požega, Požega, Hrvatska; '²veučilište u Zadru, Odjel za psihologiju, Zadar, Hrvatska I'Julije Kempf Elementary School in Požega, Požega, Croatia; '2 University of Zadar, Department of Psychology, Zadar, Croatia

ORCID ID: 0000-0002-8747-8036

ORCID ID: 0000-0002-4215-3668

Lucidni su snovi hibridni fenomeni između spavanja i budnosti, s velikim terapijskim potencijalom. Tako je moguće proučavati kontinuitet psihopatologije i emocionalne regulacije u budnosti i snovima putem obrambenih mehanizama. Dosadašnja malobrojna istraživanja potvrđuju da multidimenzionalan pristup lucidnom sanjanju posljedično ima drugačije implikacije u objašnjenju (mal)adaptivnosti ovog fenomena za psihičko zdravlje. Cilj ovog istraživanja bio je ispitati odnose pojedinih dimenzija lucidnog sanjanja s varijablama psihopatološkog distresa. Upitnik obrambenih stilova (DSQ-40), Kratki inventar simptoma (BSI) te Upitnik frekvencije i intenziteta lucidnosti (FILD) primijenjeni su u online uzorku od 665 sudionika. Prvi put primijenjen na hrvatskom uzorku, FILD upitnik je pokazao zadovoljavajuće psihometrijske karakteristike. Sukladno hipotezi kontinuiteta, utvrđene su značajne pozitivne povezanosti negativnih emocija, broja buđenja, tehnika indukcije te frekvencije lucidnosti sa simptomima psihopatologije. Štoviše, dobivene su negativne značajne povezanosti kvalitete spavanja, želje za novim lucidnim snom, pozitivnih emocija te intenziteta lucidnosti sa ispitanim simptomima, kao i različiti obrasci povezanosti obrambenih mehanizama s dimenzijama lucidnosti u snovima. Dobiveni rezultati pokazuju kako su, pored kvalitete spavanja, broja buđenja i želje za novim lucidnim snom, emocionalnost i tehnike indukcije važne odrednice psihološke dobrobiti lucidnih sanjača. Ovo ja bitan pomak u dosadašnjim istraživanjima i razumijevanju višedimenzionalnosti lucidnog sanjanja.

/ Lucid dreams are hybrid phenomena between sleep and wakefulness, with great therapeutic potential. Thus, it is possible to study the continuity of psychopathology and emotional regulation in wakefulness and dreams through defense mechanisms. Only few studies so far have confirmed that a multidimensional approach to lucid dreaming consequently has different implications in explaining the (mal)adaptability of this phenomenon to mental health. The aim of this study was to examine the relationships of different dimensions of lucid dreaming with variables of psychopathological distress. The Defense Style Questionnaire (DSQ-40), the Short Symptom Inventory (BSI) and the Frequency and Intensity Questionnaire (FILD) were applied online in a sample of 665 participants. First applied to a Croatian population sample, the FILD questionnaire showed satisfactory psychometric characteristics. According to the continuity hypothesis, significant positive associations of negative emotions, number of awakenings, induction techniques and frequency of lucid dreams with symptoms of psychopathology were found. Moreover, negative significant correlations between sleep quality, desire for a new lucid dream, positive emotions and intensity of lucid dreams with the examined symptoms were found, as well as different patterns of defense mechanisms with lucidity dimensions in dreams. The obtained results show that, in addition to the quality of sleep, the number of awakenings and the desire for a new lucid dream, emotionality and induction techniques are important determinants of the psychological well-being of lucid dreamers. This represents a significant shift in research and understanding of the multidimensionality of lucid dreaming so far. 


\section{ADRESA ZA DOPISIVANJE /} CORRESPONDENCE:

Mag. psych. Marija Ivanović

Osnovna škola Julija Kempfa Požega

Dr. Franje Tuđmana 2

34000 Požega, Hrvatska

E-pošta: marija.ivanovic667@gmail.com

\section{KLJUČNE RIJEČI / KEY WORDS:}

Lucidni snovi / Lucid Dreams

Obrambeni mehanizmi / Defence Mechanisms

Psihopatološki simptomi / Psychopathological Symptoms

TO LINK TO THIS ARTICLE: https://doi.org/10.24869/spsih.2021.93

\section{UVOD}

Tijekom spavanja u odnosu na budnost, značajke svijesti bitno se mijenjaju. To je još Freud (1) opisao primitivnim, animalističkim mišljenjem, koje je danas neurobiološki potvrđen regresivnim oblikom kognicije. Snovi najčešće nastaju u REM fazi spavanja, kad se električna aktivnost mozga smanjuje u području prefrontalnog korteksa čime su onemogućene sposobnosti uvida, logičnog mišljenja i donošenja odluka (2). Spavač je tako pasivan, bez kontrole nad radnjom sna, a samo je iskustvo sanjanja dinamično i emocionalno intenzivno kao stvarnost (3). U odnosu na kvantitativne, ovakvi kvalitativni aspekti spavačeve svijesti, poput paralize spavanja, hipnagognih halucinacija i konfuzija pri buđenju (4), još uvijek su manje istraženi. Watson (5) je empirijski podijelio iskustva pri spavanju na mnoštvo netipičnih fenomena pri sanjanju (i prijelazima k budnosti) te na doživljaj lucidnosti u snovima, što je definirao kao svijest pojedinca da sanja tijekom sna te da ima kontrolu nad radnjom sna.

Ovaj fenomen odavno ima kulturološko i religijsko značenje (6). Udaljavanjem od spiritualizma i parapsihologije dvadesetim stoljećem počinju znanstvena istraživanja lucidnosti $(7,8)$. Od 1970-ih, u sklopu transpersonalne psihologije ispituje se odnos s meditacijom i psihološkim blagostanjem (9). Hearne (10) je ubrzo demonstrirao da motorička aktivnost nije potpuno inhibirana tijekom REM spa-

\section{INTRODUCTION}

During sleep as opposed to wakefulness, the characteristics of consciousness change significantly. This was described by Freud (1) in primitive, animalistic thinking, which is today neurobiologically confirmed by a regressive form of cognition. Dreams are the most common in REM sleep, when brain activity decreases in the area of the prefrontal cortex, impeding insights, logical opinions and decision making (2). Therefore, the sleeper is passive, without control over the action of the dream, and the experience of dreaming is as dynamic and emotionally intense as reality (3). Compared with the quantitative aspects of sleep, these qualitative aspects of sleep consciousness, such as sleep paralysis, hypnagogic hallucinations and waking confusion (4), are still less explored. Watson (5) empirically divided sleep experiences into a multitude of atypical phenomena in dreaming (and transitions to wakefulness) and the experience of lucidity in dreams, which he defined as an individual's awareness to dream during a dream and to have control over a dream.

This phenomenon has long had cultural and religious significance (6). By moving away from spiritualism and parapsychology, scientific research into lucidity began in the twentieth century $(7,8)$. Since the 1970s, as part of transpersonal psychology, the relationship with meditation and psychological well-being has been examined (9). Hearne (10) soon demonstrated that motor activity is not completely inhibited during REM sleep. His technique of signaling the onset of lucidity with 
vanja. Njegovu tehniku signalizacije početka lucidnosti voljnim okulomotornim pokretima usvojio je i La Berge (11), čime je započela era psihofizioloških i neurobioloških ispitivanja. Daljnjim je istraživanjima lucidnost potvrđena kao hibridno stanje svijesti sa značajkama i budnosti i nelucidnog sna. U određenim su moždanim strukturama utvrđene strukturne i fiziološke razlike pri pojavi lucidnih u odnosu na nelucidne REM snove (12), što može objasniti njihovu različitu fenomenologiju. Lucidni su snovi tako popraćeni višom razinom dosjećanja, uvida, kontrole, refleksivnosti, disocijacije te pozitivnih emocija. Isto ne vrijedi za njihovu realističnost i popratne negativne emocije. Sadržajno gledano, postoji više sličnosti nego razlika pa u lucidnim snovima i dalje mogu perzistirati iracionalne misli, njihovo dosjećanje nije uvijek učestalije te je percepcija i dalje vrlo slična onoj u budnosti (13).

Moderna su istraživanja utvrdila osnovna obilježja lucidnih snova, a najvažnije je uvid, metakognitivna spoznaja o trenutnom stanju svijesti tijekom sna (14). Kontrola tijekom sna omogućava manipuliranje radnjom, a disocijativnim mišljenjem lucidni sanjač zauzima perspektivu treće osobe. Česti su izvještaji u kojima sanjači cijele scene lucidnosti vide poput filma na zaslonu (11). Pri uvježbavanju određenih radnji podudaraju se obrasci aktivnosti određenih kortikalnih regija i fizioloških parametara u lucidnom i budnom stanju (11), što može objasniti rezultate istraživanja (15) koji potvrđuju da je uvježbavanje određene radnje jednako učinkovito u oba stanja.

Lucidnost u snu doživi barem jednom tijekom života $55 \%$ populacije, a $23 \%$ barem jednom mjesečno (16). Incidencija spontane lucidnosti raste tijekom djetinjstva i adolescencije, $s$ vrhuncem u dobi od 16 godina, a potom ubrzano opada. Okidači takve nenamjerne lucidnosti najčešće su noćne more i emocije poput srama i ushita (17). Zahvaljujući tehnikama indukcije, lucidnost može postati i dobro naučena vješti- voluntary oculomotor movements was also adopted by La Berge (11), thus beginning the era of psychophysiological and neurobiological research. Further research confirmed lucidity as a hybrid state of consciousness, with features of both wakefulness and non-lucid sleep. In certain brain structures, structural and physiological differences were found in the occurrence of lucid versus non-lucid REM dreams (12), which may explain their different phenomenology. Lucid dreams are thus accompanied by a higher level of memory recall, insight, control, reflexivity, dissociation and positive emotions. This was not confirmed with regard to their realism and accompanying negative emotions. In terms of their content there are more similarities than differences, so irrational thoughts can still persist in lucid dreams, their recall is not always more frequent and the perception is still very similar to that in wakefulness (13).

Modern studies have established the basic characteristics of lucid dreams, the most important of which is insight, i.e. metacognitive cognition of the current state of consciousness during the dream (14). Control during dream ensures manipulation of actions, and the lucid dreamer takes a third-person perspective by dissociative thinking. There are frequent reports in which dreamers see the whole scene of lucidity like a movie on a screen (11). When practicing specific actions, the patterns of activity of corresponding cortical regions and physiological parameters in lucid and awake states (11) coincide, which may explain the results of studies (15) which confirm that practicing certain actions is equally effective in both states.

$55 \%$ of the population experience lucidity in a dream at least once in life and $23 \%$ experience it at least once a month (16). The incidence of spontaneous lucidity increases during childhood and adolescence, peaking at age 16 and then declining rapidly. The triggers of such unintentional lucidity are most often nightmares and emotions such as shame and elation (17). Thanks to induction techniques, lucidity can also become a well-learned skill. In dreams, there are frequent 
na. U snovima su česte distorzije u kvantiteti i kakvoći objekata iz budnosti, koje osviještene u snu naznačuju početak lucidnosti (17). Ipak, nijedna od poznatih tehnika nije dovoljno verificirana kao valjana metoda indukcije (18).

Istraživanja lucidnosti upitničkom metodom nedovoljno su česta. U ovom je području očita i heterogenost istraživačkog pristupa, koja proizlazi iz samih kriterija lucidnosti utemeljenih na uvidu i/ili kontroli nad radnjom sna. Prva su istraživanja lucidne snove ispitivala jednom česticom, npr. „Koliko često doživljavate tzv. lucidne snove?" (19) i "Jeste li ikada imali san tijekom kojeg ste znali da sanjate?” (20), što se ubrzo pokazalo nedovoljno osjetljivom mjerom. Prvu ljestvicu lucidnosti predložio je Watson (5), dok su Voss i sur. (14) konstruirali obuhvatniju mjeru. Najveći doprinos ipak su dale autorice Aviram i Soffer-Dudek (21), razvojem Upitnika frekvencije i intenziteta lucidnih snova (FILD), koji se temelji na opširnijoj definiciji ovog fenomena i mjeri četiri dimenzije: frekvenciju, intenzitet i emocionalnu valenciju lucidnih snova te frekvenciju korištenja sedam tehnika indukcije.

Nekonzistentni rezultati dosadašnjih istraživanja o povezanosti između lucidnosti s depresijom $(22,23)$, posttraumatskim stresnim poremećajem $(24,25)$, disocijacijom $(5,23,25-27)$ i shizotipijom $(5,27)$ mogu se, barem dijelom objasniti i različitim operacionalizacijama lucidnosti. Ispitujući ovaj fenomen s ostalim noćnim fenomenima povezanima sa shizotipijom i doživljajima disocijacije (5), lucidnost je promatrana kao intruzivna pobuđenost u snu $(4,23)$, rani biljeg prikrivenog distresa (28) te indikator loše kvalitete spavanja (4). Međutim, 65 \% lucidnih sanjača naglašava njene prednosti, poput psihičkog i duhovnog blagostanja (29). Prema istraživanjima, unutarnji lokus kontrole, psihološka otpornost (23), bolje opće mentalno zdravlje (30) te asertivnost, autonomija i samopouzdanje (31) također su bitne odlike lucidnih sanjača. Dimenzionalnim pristupom distortions in the quantity and quality of objects from wakefulness, which indicate the beginning of lucidity (17). However, none of the known techniques has been sufficiently verified as a valid method of induction (18).

Questionnaire-based lucidity research is insufficiently common. The heterogeneity of the research approach is also evident in this area, which arises from the very criteria of lucidity based on insight and / or control over dream activity. The first studies examined lucid dreams with a single particle, e.g. "How often do you experience the so-called lucid dreams?" (19) and "Have you ever had a dream during which you knew you were dreaming?" (20), which soon proved to be an insufficiently sensitive measure. The first scale of lucidity was proposed by Watson (5), while Voss et al. (14) constructed a more comprehensive measure. However, the greatest contribution was made by the authors Aviram and Soffer-Dudek (21), with the development of the Frequency and Intensity of Lucid Dreams Questionnaire (FILD), which is based on a broader definition of this phenomenon and measures four dimensions: frequency, intensity and emotional valence of lucid dreams and the frequency of using seven induction techniques.

Inconsistent results of previous research on the association between lucidity with depression (22-23), post-traumatic stress disorder $(24,25)$, dissociation (5, 23, 25-27) and schizotyping (5, 27) can be explained, at least in part, by different operationalizations of lucidity. By examining this phenomenon with other nocturnal phenomena associated with schizotypy and dissociative experiences (5), lucidity was observed as intrusive arousal in sleep $(4,23)$, an early marker of latent distress (28), and a poor sleep quality indicator (4). However, $65 \%$ of lucid dreamers emphasize its benefits, such as mental and spiritual well-being (29). According to studies, internal locus of control, psychological resilience (23), better general mental health (30), assertiveness, autonomy, and self-confidence (31) are also essential characteristics of lucid dreamers. With the introduction of the dimensional approach, the relationship 
odnos između lucidnosti i mentalnog zdravlja postao je jasniji (21). Naime, potvrđeno je da frekvencija izazvanih lucidnih snova pozitivno predviđa simptome disocijacije i shizotipije, dok svijest u snu ne pridonosi psihološkoj dobrobiti ni distresu. Nadalje, ključnim se pokazala sanjačeva percepcija pobuđenosti, tj. lucidnost visokog intenziteta i pozitivnog afekta implicira manje distresa u odnosu na svijest bez kontrole, popraćenu negativnim afektima (21).

Prema psihodinamskom pristupu, snovi su kraljevski put do nesvjesnoga (32). Povezani su s obrambenim mehanizmima, najranijim oblicima emocionalne regulacije koji štite od anksioznosti zbog intrapsihičkih konflikata i doprinose psihološkoj prilagodbi. Kad su zreli, obrambeni mehanizmi predviđaju mentalno i tjelesno zdravlje (33). Međutim, predugim i rigidnim korištenjem postaju maladaptivni pa ne čudi njihov pozitivan odnos sa psihopatologijom (34). Odnos obrana i mentalnog zdravlja vrlo je dinamičan, a rad na snovima može potaknuti psihoterapijski napredak usvajanja adaptivnijih obrana jer se tako postiže manji otpor ega (35). Lucidni snovi omogućavaju sanjaču i aktivno suočavanje s npr. objektom straha, u sigurnim uvjetima. Tako sanjač integrira nove osjećaje prema sebi i okolini, umjesto da izbjegava suočavanje u budnosti i/ili se budi iz noćnih mora (18). Naime, procesiranje i regulacija emocija posebno su facilitirani tijekom REM snova, što podržava iste procese i tijekom budnosti (17). Prethodno navedeno objašnjava i tzv. hipoteza kontinuiteta, prema kojoj su snovi odraz vidljivih i prikrivenih aspekata budnosti. Ovu sukladnost budnih iskustava sa snovima moguće je proučavati na više razina. Jedna od njih je i zrelost osobne emocionalne regulacije koja se empirijski može ispitati pomoću obrambenih mehanizama (36). Stoga se odnos obrana, (lucidnih) snova i psihopatologije potencijalno može objasniti i kao kontinuitet emocionalne regulacije u budnosti i snovima. between lucidity and mental health has become clearer (21). Namely, it was confirmed that the frequency of induced lucid dreams positively predicts symptoms of dissociation and schizotyping, while arousal in dreams does not contribute to psychological well-being or distress. Furthermore, the dreamer's perception of arousal has been shown to be crucial, i.e., high intensive lucidity accompanied by positive affects implies less distress compared with uncontrolled consciousness accompanied by negative affects (21).

According to the psychodynamic approach, dreams are the royal path to the unconscious (32). They are associated with defense mechanisms, the earliest forms of emotional regulation, which protect against anxiety due to intrapsychic conflicts and contribute to psychological adjustment. When mature, defense mechanisms predict mental and physical health (33). However, with too long and rigid use, they become maladaptive, so their positive relationship with psychopathology is not surprising (34). The relationship between defenses and mental health is very dynamic, and working on dreams can encourage psychotherapeutic progress in adopting more adaptive defenses, because less ego resistance is achieved in this way (35). Lucid dreams enable the dreamer to actively deal with, for example, the object of fear in safe conditions. Thus, the dreamer integrates new feelings towards himself and the environment, instead of avoiding confrontation in wakefulness and/or waking up from nightmares (18). Namely, emotion processing and regulation are particularly facilitated during REM dreams, which supports the same processes during wakefulness (17). The above also explains the so-called continuity hypothesis, according to which dreams reflect visible and veiled aspects of wakefulness (36). This consistency of waking experiences with dreams can be studied at multiple levels. One of them is the maturity of personal emotional regulation, which can be empirically examined using defense mechanisms. Therefore, the relationship between defenses, (lucid) dreams and psychopathology can potentially be explained as a continuity of emotional regulation in wakefulness and dreams. 
Cilj ovog istraživanja bio je provjeriti psihometrijske karakteristike FILD upitnika te potom ispitati odnose različitih dimenzija lucidnosti sa simptomima psihopatologije i obrambenim mehanizmima u kontekstu hipoteze kontinuiteta.

\section{METODA}

\section{Uzorak}

Uzorak je činilo 665 sudionika, većinom studenti $(59,70 \%)$ i žene (72,93\%), raspona dobi od 17 do 44 godine $(M=22,10 ; S D=3,53)$. Sudionici najčešće pate od simptoma nesanice $(29,17 \%)$, paralize spavanja $(15,28 \%)$, poremećaja ritma spavanja (13,19\%), noćnih strahova $(6,25 \%)$, sindroma nemirnih nogu $(5,56 \%)$, mjesečarenja (4,86 \%) i narkolepsije $(1,39 \%)$.

\section{Instrumentarij}

Upitnik frekvencije i intenziteta lucidnih snova FILD (21) sadrži ukupno 21 česticu i obuhvaća četiri dimenzije: frekvencija (trenutna, produžena, spontana, pokušaji indukcije, uspješna indukcija), intenzitet (sigurnost, aktivnost, kontrola, trajanje u sekundama/minutama, broj scena) i emocionalna valencija lucidnih snova (pozitivna početak, negativna početak, pozitivna kraj, negativna kraj) te tehnike indukcije lucidnosti (dnevnik spavanja, čitanje, misli tijekom budnosti i prije spavanja, provjera stvarnosti, planiranje izmjena spavanja i budnosti, napredne tehnike). Na čestice vezane uz frekvenciju daju se procjene čestine u rasponu od 0 („Nikada.“) do 7 („Dva puta tjedno i češće."), a uz intenzitet, u rasponu od 0 (nesigurnost/ pasivnost/bez kontrole u 80-100 \% slučajeva i „Kad shvatim da sanjam, probudim se.") do 4 (sigurnost/aktivnost/kontrola u 80-100 \% slučajeva i „Obično moja lucidnost traje 6 minuta $i$ duže./ Obično doživim 4 i više lucidnih scena.").
The aim of this study was to verify the psychometric characteristics of the FILD questionnaire and to then examine the relationships between different dimensions of lucidity and the symptoms of psychopathology and defense mechanisms in the context of the continuity hypothesis.

\section{METHOD}

\section{Sample}

The sample consisted of 665 participants, mostly students (59.70\%) and women (72.93\%), ranging in age from 17 to 44 years $(M=22.10 ; S D=3.53)$. Participants most often suffer from symptoms of insomnia (29.17\%), sleep paralysis (15.28\%), sleep rhythm disorder (13.19\%), night terrors (6.25\%), restless legs syndrome (5.56\%), somnambulism (4.86\%) and narcolepsy (1.39\%).

\section{Instruments}

The Frequency and Intensity of Lucid Dreams Questionnaire (21) contains a total of 21 items and includes four dimensions: frequency (momentary, prolonged, spontaneous, induction attempts, successful induction), intensity (confidence, activity, control, duration in seconds / minutes, number of scenes) and emotional valence of lucid dreams (positive beginning, negative beginning, positive ending, negative ending) and lucidity induction techniques (dream diary, reading, thoughts during and before sleep, reality checking, planning sleep time, advanced techniques). On frequency-related items, estimates are given ranging from 0 ("Never.) to 7 ("Twice a week and more often."), and on intensity items they range from 0 (uncertainty/passivity/no control in 80$100 \%$ of cases and "When I realize I'm dreaming, I wake up.") up to 4 (confidence/activity/control in $80-100 \%$ of cases and "Usually my lucidity lasts 6 minutes and longer. / I usually experience 4 or more lucid scenes."). On two emotion-related items estimates before the onset of lucidity are given ranging from 0 ("0\% None of my lucid dreams start positively/negatively.") to 10 ("100\% All my 
Na dvjema česticama vezanim uz emocije prije pojave lucidnosti odgovara se u rasponu od 0 („,0\% Nijedan moj lucidni san ne započinje pozitivno/negativno.“) do 10 („,100\% Svi moji lucidni snovi započinju pozitivno/negativno."). Na isti se način odgovara na čestice vezane uz emocije koje slijede lucidnost, od 0 (,0\% Nikad se ne osjećam dobro/loše nakon postizanja lucidnosti.") do 10 („100\% Uvijek se osjećam dobro/loše nakon postizanja lucidnosti.“). Rezultati na podljestvicama formiraju se kao prosjek rezultata postignutih na pripadajućim česticama, s tim da se negativne emocije prije i nakon lucidnosti prvo rekodiraju. Viši rezultati ukazuju na veću učestalost doživljavanja i veći intenzitet lucidnih snova te pozitivnije emocije koje prethode/slijede lucidnost u snu. Na isti se način formiraju i interpretiraju rezultati podljestvice tehnike indukcije, a procjene se daju u rasponu od 0 („Nikada.") do 5 („Tri puta i više tijekom prošlog mjeseca."). Za potrebe ovog istraživanja, dobiveno je odobrenje za korištenje FILD upitnika od strane autorica (21) a upitnik je preveden na hrvatski jezik.

S obzirom na neistraženost fenomena lucidnosti, za potrebe ovog istraživanja osmišljene su dodatne čestice kojima se ispitala želja za novim lucidnim snom, tipična radnja i dosjećanje lucidnih snova te broj buđenja i kvaliteta spavanja u tipičnoj noći u kojoj su sudionici lucidno sanjali. Na pitanje „Biste li htjeli ponovno doživjeti novi lucidni san?", odgovaralo se u rasponu od „0 - Ne.“, preko „1 - Nisam siguran/na.“" do „2 - Da.“. Viši je rezultat ukazivao na pozitivniji stav prema novom lucidnom snu. Pri opisu tipične radnje i dosjećanja, uz opciju „Ostalo“, dane su procjene u rasponu od 1 („Doživljavam kratkotrajne i apstraktne elemente lucidnosti bez konkretnog sadržaja kojeg se sjećam") preko 2 („Nasumične radnje nepovezane jedna s drugom tijekom jednog lucidnog sna.") do 3 („Jedna smislena radnja koja se nastavlja kroz bar dva lucidna sna") te na ljestvici s krajnjim vrijednostima 0 („0\% Ne sjećam se radnje svog lucidnog sna.“) i 10 lucid dreams start positively/negatively."). Items related to emotions that follow lucidity have the same range, from 0 ("0\% I never feel good/bad after achieving lucidity.") to 10 ("100\% I always feel good/bad after achieving lucidity."). The results on the subscales are calculated as the average of the results achieved on the corresponding items, with the negative emotions before and after lucidity being recoded first. Higher results indicate a higher frequency of experiences with lucidity, higher intensity of lucid dreams and more positive emotions that precede/follow lucidity in dreams. The results of the induction technique subscale are formed and interpreted in the same way, and estimates are given in the range from 0 ("Never.") to 5 ("Three times or more during the last month."). For the purposes of this study, approval was obtained for the use of the FILD questionnaire by the authors (21) and the questionnaire was translated into Croatian.

Considering the unexplored phenomenon of lucidity, additional items were designed for the purposes of this study to examine the desire for a new lucid dream, typical plot and recall of lucid dreams, the number of awakenings and sleep quality on a typical night in which participants lucidly dreamed. Possible answers to the question "Would you like to experience a new lucid dream?" ranged from "0-No." through "1-I'm not sure." to "2-Yes.". The higher score indicated a more positive attitude toward the new lucid dream. When describing a typical plot and its recall rates, in addition to the "Other" option, estimates ranged from 1 ("I experience short-lived and abstract elements of lucidity without a specific narrative I remember") and 2 ("Random actions unrelated to each other during a lucid dream.") to 3 ("One meaningful action that continues through at least two lucid dreams.") and on a scale with end values of 0 (" $0 \%$ I don't remember the narrative of my lucid dream.") and 10 ("100\% I remember the narrative of my lucid dream."). The higher score indicated more meaningful narrative and their more frequent recall. When assessing the number of awakenings and the quality of sleep, estimates are given ranged from 0 ("I have an un- 

nog sna.").Viši je rezultat ukazivao na veću smislenost i češće dosjećanje sadržaja radnje. Pri procjeni broja buđenja i kvalitete spavanja procjene su dane u rasponu od 0 („Imam neprekinut san cijelu noc“) do 3 („Budim se tri i više puta tijekom noci.“) te od 0 („Osjećam se iscrpljeno $i$ umorno.“) do 4 („.. Osjećam se svježe i odmoreno.“).

Upitnik obrambenih stilova DSQ-40 (37) sadrži 40 čestica koje ispituju svjesne aspekte 20 obrana na koje se odgovara u rasponu od 1 („Uopće se ne slažem.“) do 9 („U potpunosti se slažem."). Individualni je rezultat prosjek dviju čestica pripadajućih određenoj obrani, odnosno obrana pripadajućih određenom obrambenom stilu. Tako se ovim upitnikom dobivaju informacije o 20 obrana grupiranih kao: zrele (sublimacija, humor, anticipacija, supresija), nezrele (projekcija, pasivna agresija, izvođenje, izolacija, devaluacija, autistična fantazija, poricanje, premještanje, disocijacija, raščlanjivanje, racionalizacija, somatizacija) i neurotske (negiranje, pseudoaltruizam, idealizacija, reaktivna formacija). Upitnik je validiran na hrvatskom uzorku studenata (38), a koeficijenti Cronbach alfa pouzdanosti za zrele, neurotske i nezrele obrane $(0,52,0,50$ i 0,71$)$ nešto su niži od dobivenih u ovom istraživanju $(0,67,0,63$ i 0,79$)$.

Kratki inventar simptoma BSI (Brief Symptom Inventory) (39) sadrži 53 čestice i mjeri devet dimenzija trenutnih simptoma izazvanih stresnim događajima: somatizacija, opsesivna kompulzivnost, osjetljivost u međuljudskim odnosima, depresija, anksioznost, neprijateljstvo, fobičnost, paranoidne ideje, psihoticizam. Čestice se procjenjuju u rasponu od nula („Nimalo.") do četiri („Vrlo mnogo“). Individualan je rezultat prosjek čestica pripadajućih određenoj dimenziji. Procjena je moguća i putem indeksa ukupnih teškoća, prisutnih simptoma nelagode i ukupnih prisutnih simptoma. Tri globalna indeksa, devet dimenzija i 53 čestice tako daju tri razine interpretacije, od opće mjere psihološkog statusa, preko reprezentacije sindroma or more times during the night") and from 0 ("I feel exhausted and tired") to 4 ("I feel fresh and rested.").

The Defense Styles Questionnaire DSQ-40 (37) contains 40 items that examine conscious aspects of 20 defenses, to which possible answers range from 1 ("I completely disagree.") to 9 ("I completely agree."). The individual result is the average of two items belonging to a certain defense, i.e. the defense belonging to a certain defensive style. Thus, this questionnaire provides information on 20 defenses grouped as: mature (sublimation, humor, anticipation, suppression), immature (projection, passive aggression, acting out, isolation, devaluation, autistic fantasy, denial, displacement, dissociation, splitting, rationalization, somatization) and neurotic (denial, pseudoaltruism, idealization, reactive formation). The questionnaire was validated on a Croatian sample of students (38), and the Cronbach alpha reliability coefficients for mature, neurotic and immature defenses $(0.52,0.50$ and 0.71$)$ were slightly lower than those obtained in this study $(0.67,0.63$ and 0.79).

The Brief Symptom Inventory (BSI) (39) contains 53 items and measures nine dimensions of current symptoms caused by stressful events: somatization, obsessive-compulsiveness, sensitivity in interpersonal relationships, depression, anxiety, hostility, phobia, paranoid ideas and psychoticism. Estimates are given in a range from 0 ("Not at all") to 4 ("Very much"). The individual result is the average of the items belonging to a certain dimension. Assessment is also possible through an index of total difficulty, present symptoms of discomfort and total present symptoms. Three global indices, nine dimensions, and 53 items thus provide three levels of interpretation, from a general measure of psychological status, through a representation of the syndrome, to individual symptoms. The one-factor structure of the inventory was confirmed on a Croatian sample of traumatized and general populations, and Cronbach's alpha confidence coefficients for the general population ranged from 0.69 for psychoticism to 0.84 
do pojedinih simptoma. Na hrvatskom uzorku traumatiziranih i opće populacije potvrđena je jednofaktorska struktura inventara, a koeficijenti Cronbach alfa pouzdanosti za opću populaciju kretali su se od 0,69 za psihoticizam do 0,84 za somatizaciju (40). U ovom istraživanju, s rasponom od 0,72 za psihoticizam do $0,87 \mathrm{za}$ anksioznost, dobiveni su jednako zadovoljavajući koeficijenti kao i u ranijim istraživanjima (38).

\section{Postupak}

Online istraživanje Google forms oblika provođeno je tijekom travnja i svibnja 2020. godine. Putem Facebook grupa različitih interesa u najvećim gradovima $\mathrm{RH}$, potencijalni sudionici dobi između 18 i 30 godina bili su obaviješteni o istraživanju o snovima i emocijama. Zajamčena im je anonimnost, povjerljivost i mogućnost odustajanja od istraživanja. Prvo su primijenjeni DSQ-40 i BSI upitnici. Sudionici su također pitani o poremećajima spavanja od kojih pate. Zatim su popunjavali FILD upitnik $i$ to prvo pitanja koja se odnose na frekvenciju doživljavanja lucidnosti ( $N=665)$. Drugi dio FILD upitnika, koji je uključivao pitanja vezana za intenzitet i emocije, popunjavali su oni sudionici koji su doživjeli barem jedno iskustvo lucidnosti tijekom života $(N=479)$. Potom su uslijedila pitanja konstruirana u svrhu ovog istraživanja, kojima se ispitala želja za novim lucidnim snovima $(N=477)$, njihova tipična radnja i dosjećanje $(N=467)$ te broj buđenja $(N=265)$ i kvaliteta spavanja $(N=284)$ u tipičnoj lucidnoj noći. Na kraju samog istraživanja, sudionicima je zahvaljeno na sudjelovanju te je ostavljena mogućnost komentara.

\section{REZULTATI}

Prikupljeni su podatci obrađeni pomoću programa Statistica 12. Analize rezultata na FILD upitniku ukazuju da većina sudionika (59,33\%) for somatization (40). Equally satisfactory coefficients as in previous studies that ranged from 0.72 for psychoticism to 0.87 for anxiety were obtained in the present study (38).

\section{Procedure}

An online Google forms survey was conducted during April and May 2020. Potential participants aged between 18 and 30 were informed about the research on dreams and emotions through Facebook groups of different interests in the largest cities of the Republic of Croatia. They are guaranteed anonymity, confidentiality and the possibility of exiting the study. DSQ-40 and BSI questionnaires were applied first. Participants were also asked about the sleep disorders they suffer from. Then they filled in the FILD questionnaire, first of all questions related to the frequency of experiencing lucidity $(N=665)$. The second part of the FILD questionnaire, which included questions related to intensity and emotions, was completed by those participants who had at least one experience of lucidity during their lifetime $(\mathrm{N}=$ 479). This was followed by questions constructed for the purpose of this study, which examined the desire for new lucid dreams $(\mathrm{N}=477)$, their typical narrative and their recall $(\mathrm{N}=467)$, the number of awakenings $(\mathrm{N}=265)$ and quality of sleep $(\mathrm{N}=284)$ in a typical lucid night. At the end of the study, the participants were thanked for their participation and provided the opportunity to comment.

\section{RESULTS}

The collected data were processed using the Statistica program 12. Analysis of the results on the FILD questionnaire indicated that the majority of participants (59.33\%) wanted to experience a new lucid dream. More of them (44.11\%) experienced random dream narratives than meaningful ones (34.05\%) or short-term and abstract elements of lucidity (17.56\%). The results on the measure of recalling the narrative of lucid dreams 

doživljava nasumične radnje, nego jednu smislenu (34,05 \%) ili kratkotrajne i apstraktne elemente lucidnosti (17,56 \%). Rezultati na mjeri dosjećanja radnje lucidnih snova pomaknuti su prema višim vrijednostima ( $M=6,41$; $S D=2,62$ ). Kada je riječ o induktivno lucidnim sanjačima, većina rezultata na procjeni broja buđenja pomaknuta je $\mathrm{k}$ nižim $(\mathrm{M}=1,05$; $\mathrm{SD}=0,90$ ), odnosno k višim vrijednostima kada je riječ o kvaliteti spavanja $(M=2,46 ; S D=1,04)$.

U svrhu validacije FILD upitnika, slijeđene su preporuke autorica (21). Dobiveni indeksi asimetričnosti i spljoštenosti na podljestvicama upitnika uglavnom ne prelaze interval normalnosti distribucije u rasponu od -1 do +1 , osim za varijable vezane uz izazvanu lucidnost (tablica 1.), što je u skladu s polazišnim istraživanjem (21). Nadalje, većina sudionika (59,40\%) nikada nije ili se jako rijetko upuštala u indukciju lucidnosti.

Prema trenutnim saznanjima još uvijek nema objavljenih istraživanja koja su provjerila faktorsku strukturu FILD upitnika pa je njegova latentna struktura u ovom istraživanju provjerena eksploratornom faktorskom analizom (metoda zajedničkih faktora). Nakon Varimax rotacije dobivena je interpretabilna četvero faktorska solucija. Prvi faktor, frekvencija lucidnosti objašnjava ukupno $20,68 \%$ varijance. Drugi faktor, emocionalnost vezana uz lucidnost objašnjava $10 \%$ varijance. Treći faktor, tehnike indukcije objasnio je $8,48 \%$ varijance, a četvrti, intenzitet lucidnosti, $6,37 \%$ varijance (tablica 2.).

Zbog malog broja sudionika istraživanja autorice originalnog upitnika (21) nisu mogle provjeriti faktorsku strukturu FILD upitnika. Budući da su zaključile da emocionalnost doživljena prije lucidnosti nije indikativna za doživljene emocije nakon pojave lucidnosti, konačni su rezultati u ovom istraživanju ipak formirani na pet podljestvica (frekvencija i intenzitet lucidnosti, emocije prije i nakon lucid-

were shifted towards higher values $(M=6.41$; $\mathrm{SD}=2.62$ ). With regard to inductively lucid dreamers, most of the results in estimating the number of awakenings shifted to lower $(M=1.05$; $\mathrm{SD}=0.90$ ), or higher values when it comes to sleep quality ( $M=2.46 ; S D=1.04)$.

In order to validate the FILD questionnaire, the authors' recommendations were followed (21). The obtained skewness and kurtosis indices on the subscales of the questionnaire generally did not exceed the interval of normality of the distribution in the range from -1 to +1 , except for variables related to induced lucidity (Table 1 ), which is consistent with the baseline study (21). Furthermore, the majority of participants $(59.40 \%)$ never or very rarely indulged in lucidity induction.

According to current knowledge, there are still no published studies that have verified the factor structure of the FILD questionnaire, so its latent structure in this study was checked by exploratory factor analysis (the common factors method). After Varimax rotation, an interpretable four-factor solution was obtained. The first factor, lucid dreams frequency, explained a total of $20.68 \%$ of the variance. Another factor, lucidity-related emotionality, explained $10.00 \%$ of the variance. The third factor, induction techniques, explained $8.48 \%$ of variance, and the fourth, the intensity of lucid dreams, explained $6.37 \%$ of variance (Table 2).

Due to the small number of participants in their study, the authors of the original questionnaire (21) could not verify the factor structure of the FILD questionnaire. Since they concluded that the emotionality experienced before lucidity was not indicative of the emotions experienced after the onset of lucidity, the final results in this study were calculated on five subscales (frequency and intensity of lucid dreams, emotions before and after lucidity in dreams and induction techniques), as suggested by the authors (21). Intercorrelations of items belonging to the subscales of frequency ( $r=0.30$ to $0.79, p<0.01)$, intensity $(r=027$ to $0.65, p<0.01)$, emotion before $(r=0.66 p<0.01)$ 
TABLICA 1. Deskriptivni parametri analiziranih podljestvica upitnika FILD

TABLE 1. Descriptive parameters of the analyzed subscales of the FILD questionnaire

\begin{tabular}{|c|c|c|c|c|c|c|c|c|}
\hline & $\mathbf{N}$ & Min & $\operatorname{Max}$ & M & SD & $\begin{array}{l}\text { Asimetričnost } \\
\text { (stand. pogr.) } \\
\text { / Skewness } \\
\text { (stand. error) }\end{array}$ & $\begin{array}{c}\text { Spljoštenost } \\
\text { (stand. pogr.) } \\
\text { / Kurtosis } \\
\text { (stand, error) }\end{array}$ & Cronbach a \\
\hline Frekvencija / Frequency & 665 & 0,00 & 7,00 & 1,95 & 1,53 & $0,74(0,09)$ & $0,05(0,19)$ & 0,84 \\
\hline Trenutna / Momentary & 665 & 0,00 & 7,00 & 2,80 & 2,04 & $0,19(0,09)$ & $-0,93(0,19)$ & \\
\hline Produžena / Prolonged & 665 & 0,00 & 7,00 & 2,11 & 2,04 & $0,56(0,09)$ & $-0,80(0,19)$ & \\
\hline Spontana / Spontaneous & 665 & 0,00 & 7,00 & 2,76 & 2,10 & $0,26(0,09)$ & $-0,98(0,19)$ & \\
\hline Pokušaji / Attempts & 665 & 0,00 & 7,00 & 1,29 & 1,95 & $1,44(0,09)$ & $0,94(0,19)$ & \\
\hline Uspjeh / Success & 665 & 0,00 & 7,00 & 0,82 & 1,61 & $2,06(0,09)$ & $3,47(0,19)$ & \\
\hline Intenzitet / Intensity & 479 & 0,00 & 4,00 & 1,77 & 0,95 & $-0,06(0,11)$ & $-0,67(0,22)$ & 0,78 \\
\hline Sigurnost / Confidence & 475 & 0,00 & 4,00 & 2,04 & 1,38 & $-0,14(0,11)$ & $-1,20(0,22)$ & \\
\hline Aktivnost / Activity & 473 & 0,00 & 4,00 & 1,81 & 1,36 & $0,08(0,11)$ & $-1,22(0,22)$ & \\
\hline Kontrola / Control & 470 & 0,00 & 4,00 & 1,46 & 1,30 & $0,41(0,11)$ & $-1,05(0,22)$ & \\
\hline Trajanje / Length & 472 & 0,00 & 4,00 & 1,90 & 1,21 & $-0,00(0,11)$ & $-0,99(0,22)$ & \\
\hline Scene / Scenes & 475 & 0,00 & 4,00 & 1,69 & 1,19 & $0,46(0,11)$ & $-0,64(0,22)$ & \\
\hline Emocije prije / Emotions before & 471 & 0,00 & 10,00 & 5,31 & 2,54 & $-0,16(0,11)$ & $-0,72(0,22)$ & 0,82 \\
\hline Pozitivno prije / Positive beginning & 451 & 0,00 & 10,00 & 5,19 & 2,68 & $-0,25(0,11)$ & $-0,70(0,23)$ & \\
\hline Negativno prije / Negative beginning & 471 & 0,00 & 10,00 & 5,45 & 2,82 & $-0,16(0,11)$ & $-0,94(0,22)$ & \\
\hline Emocije nakon / Emotions after & 467 & 0,00 & 10,00 & 5,82 & 2,65 & $-0,37(0,11)$ & $-0,60(0,23)$ & 0,84 \\
\hline Pozitivno nakon / Positive ending & 469 & 0,00 & 10,00 & 5,77 & 2,79 & $-0,41(0,11)$ & $-0,68(0,23)$ & \\
\hline Negativno nakon / Negative ending & 469 & 0,00 & 10,00 & 5,87 & 2,91 & $-0,34(0,11)$ & $-0,87(0,23)$ & \\
\hline Tehnike indukcije / Induction techniques & 278 & 0,00 & 4,00 & 0,73 & 0,65 & $1,63(0,15)$ & $3,69(0,29)$ & 0,77 \\
\hline Dnevnik spavanja / Dream diary & 278 & 0,00 & 4,00 & 0,59 & 1,08 & $2,14(0,15)$ & $3,89(0,29)$ & \\
\hline Čitanje / Reading & 278 & 0,00 & 4,00 & 0,84 & 0,86 & $1,60(0,15)$ & $3,43(0,29)$ & \\
\hline Dnevne misli / Daily thoughts & 275 & 0,00 & 4,00 & 1,17 & 1,14 & $1,00(0,15)$ & $0,29(0,29)$ & \\
\hline Provjera stvarnosti / Reality checks & 274 & 0,00 & 4,00 & 0,62 & 1,03 & $1,94(0,15)$ & $3,26(0,29)$ & \\
\hline Planiranje spavanja / Planning sleep time & 274 & 0,00 & 4,00 & 0,55 & 1,04 & $2,05(0,15)$ & $3,39(0,29)$ & \\
\hline Napredne tehnike / Advanced techniques & 275 & 0,00 & 4,00 & 0,32 & 0,76 & $2,80(0,15)$ & $8,11(0,29)$ & \\
\hline Misli prije sna / Thoughts at bedtime & 272 & 0,00 & 4,00 & 1,04 & 1,22 & $1,05(0,15)$ & $0,06(0,29)$ & \\
\hline
\end{tabular}

nosti u snu i tehnike indukcije), kako predlažu autorice (21). Interkorelacije čestica pripadajućih podljestvica frekvencije $(r=0,30$ do 0,79 , $\mathrm{p}<0,01)$, intenziteta $(\mathrm{r}=0,27$ do $0,65, \mathrm{p}<0,01)$, emocija prije $(r=0,66, p<0,01)$ i nakon $(r=0,66$, $\mathrm{p}<0,01)$ pojave lucidnosti te tehnika indukcije lucidnosti $(r=0,21$ do $0,48, p<0,01)$ značajne su i pozitivne te su njihove vrijednosti u zadovoljavajućim rasponima. Kada je riječ o povezanosti rezultata na pojedinim podljestvicama, one and after $(r=0.66, p<0,01)$ occurrence of lucidity and lucidity induction techniques ( $\mathrm{r}=0.21$ to 0.48 , $\mathrm{p}<0.01$ ) were significant and positive and their values were in satisfactory ranges. The correlation of results on different subscales was also significant and positive and ranged from $0.15(\mathrm{p}<0.05)$ (between intensity and emotions that follow lucidity subscales) to $0.40(\mathrm{p}<0.01)$ (between frequency and intensity subscales), i.e. $0.44(\mathrm{p}<0.01)$ (between emotion before and after lucidity sub- 
TABLICA 2. Rezultata eksploratorne faktorske analize (Varimax normalized) čestica FILD upitnika na hrvatskom uzorku mladih TABLE 2. The results of exploratory factor analysis (Varimax normalized) of FILD questionnaire items on the Croatian youth sample

\begin{tabular}{|c|c|c|c|c|}
\hline & $\begin{array}{c}\text { Faktor } 1 / \\
\text { Factor } 1\end{array}$ & $\begin{array}{c}\text { Faktor } 2 / \\
\text { Factor } 2\end{array}$ & $\begin{array}{l}\text { Faktor } 3 \text { / } \\
\text { Factor } 3\end{array}$ & $\begin{array}{c}\text { Faktor } 4 \text { / } \\
\text { Factor } 4\end{array}$ \\
\hline Trenutna / Momentary & 0,69 & $-0,09$ & 0,04 & $-0,07$ \\
\hline Produžena / Prolonged & 0,79 & $-0,04$ & 0,13 & 0,28 \\
\hline Spontana / Spontaneous & 0,78 & $-0,04$ & 0,02 & 0,10 \\
\hline Pokušaji / Attempts & 0,58 & 0,19 & 0,20 & 0,22 \\
\hline Uspjeh / Success & 0,61 & 0,09 & 0,17 & 0,38 \\
\hline Sigurnost / Confidence & 0,14 & 0,07 & 0,07 & 0,49 \\
\hline Aktivnost / Activity & 0,01 & 0,10 & $-0,02$ & 0,67 \\
\hline Kontrola / Control & 0,02 & 0,13 & 0,08 & 0,74 \\
\hline Trajanje / Length & 0,33 & $-0,05$ & 0,18 & 0,61 \\
\hline Scene / Scenes & 0,28 & $-0,07$ & 0,25 & 0,51 \\
\hline Pozitivno prije / Positive beginning & 0,15 & 0,67 & 0,05 & 0,05 \\
\hline Negativno prije / Negative beginning & 0,00 & 0,70 & 0,01 & $-0,08$ \\
\hline Pozitivno nakon / Positive ending & $-0,03$ & 0,66 & 0,03 & 0,22 \\
\hline Negativno nakon / Negative ending & $-0,13$ & 0,72 & 0,03 & 0,07 \\
\hline Dnevnik spavanja / Dream diary & 0,02 & 0,01 & 0,56 & 0,10 \\
\hline Čitanje / Reading & 0,02 & 0,08 & 0,67 & $-0,03$ \\
\hline Dnevne misli / Daily thoughts & 0,13 & 0,03 & 0,54 & 0,14 \\
\hline Provjera stvarnosti / Reality checks & 0,02 & $-0,08$ & 0,56 & 0,22 \\
\hline Planiranje spavanja / Planning sleep time & 0,03 & $-0,05$ & 0,49 & 0,05 \\
\hline Napredne tehnike / Advanced techniques & 0,09 & 0,05 & 0,62 & $-0,01$ \\
\hline Prije sna misli / Thoughts at bedtime & 0,23 & 0,21 & 0,55 & 0,03 \\
\hline Svojstvena vrijednost / Eigenvalue & 4,34 & 2,10 & 1,78 & 1,34 \\
\hline \% objašnjene varijance / \% of explained variance & 20,68 & 10,00 & 8,48 & 6,37 \\
\hline
\end{tabular}

su također značajne i pozitivne te se kreću u rasponu od 0,15 $(\mathrm{p}<0,05)$ (između podljestvica intenziteta i emocija koje slijede lucidnost) do 0,40 ( $\mathrm{p}<0,01$ ) (između podljestvica frekvencije $\mathrm{i}$ intenziteta), odnosno 0,44 ( $\mathrm{p}<0,01)$ (između podljestvica emocija prije i nakon lucidnosti). Dobivene su zadovoljavajuće vrijednosti koeficijenata Cronbach alfa pouzdanosti koje se nalaze u tablici 1 te iznose: 0,84 (frekvencija), 0,78 (intenzitet), 0,82 (emocionalna valencija prije/nakon) i 0,77 (tehnika indukcije). Dobivene vrijednosti odgovaraju vrijednostima o kojima izvještavaju autorice $(0,88,0,71,0,83$, $0,76,0,72)(21)$. scales). Satisfactory values of the Cronbach's alpha reliability coefficients are obtained, which are provided in Table 1 and were: 0.84 (frequency), 0.78 (intensity), 0.82 (emotional valence before / after) and 0.77 (induction technique). The obtained values correspond to the values reported by the authors $(0.88,0.71,0.83,0.76,0.72)(21)$. In further analyzes, Pearson correlation coefficients were calculated between lucidity dimensions and different types of defenses and psychopathological symptoms (Table 3). Prior to correlation analyzes, basic descriptive parameters were calculated and it was confirmed that the results were normally distributed. 
U daljnjima analizama izračunati su Pearsonovi koeficijenti korelacija između dimenzija lucidnosti s različitim tipovima obrana i psihopatoloških simptoma (tablica 3.). Prije korelacijskih analiza izračunati su osnovni deskriptivni parametri te je potvrđeno da se rezultati normalno distribuiraju.

Kada je riječ o frekvenciji lucidnosti, sve su dimenzije, osim pokušaja indukcije, značajno $i$ pozitivno povezane sa simptomima, posebno somatizacije, opsesivne kompulzivnosti i depresije. Više razine spontane lucidnosti značajno su povezane sa češćom uporabom zrelih, ali i nezrelih obrana. Isti su odnosi utvrđeni između anksioznosti i produžene te paranoidnosti i uspješno izazvane lucidnosti. Vezano uz intenzitet lucidnosti, utvrđene su značajne negativne povezanosti aktivnosti s neurotskim te sigurnosti s nezrelim obranama i simptomima neprijateljstva. Ipak, veći broj scena u lucidnim snovima popraćen je s češćim doživljavanjem simptoma fobičnosti (tablica 3.).

Bilo da su prethodile ili slijedile pojavu lucidnosti u snu, pozitivne emocije su značajno povezane sa češćom uporabom zrelih obrana. Nadalje, negativne emocije popraćene su češćim doživljavanjem nezrelih i neurotskih obrana te su također povezane sa svim ispitivanim simptomima, osim neprijateljstva. Iznimke od navedenog čine neznačajne povezanosti negativnih emocija prije pojave lucidnosti $\mathrm{s}$ nezrelim i neurotskim obranama kao i simptomima paranoidnosti i psihoticizma. Utvrđene su i negativne povezanosti pozitivnih emocija s određenim simptomima, npr. s fobičnosti kada je riječ o emocijama prije lucidnosti, odnosno sa somatizacijom, anksioznosti, paranoidnosti i psihoticizmom kada je riječ o emocijama koje slijede lucidnost u snu (tablica 3).

Vezano uz tehnike indukcije lucidnosti, korelacijske analize ukazuju da je učestalija provjera stvarnosti popraćena doživljavanjem viših razina svih ispitanih simptoma osim neprijateljstva. Isto je utvrđeno za misli prije
With regard to the frequency of lucidity, all dimensions except the attempt at induction were significantly and positively associated with symptoms, especially somatization, obsessive-compulsiveness and depression. Higher levels of spontaneous lucidity were significantly associated with more frequent use of mature as well as immature defenses. The same relationships were found between anxiety and prolonged, paranoid symptoms and successfully induced lucidity. Regarding the intensity of lucidity, significant negative associations between activity and neurotic defenses as well as between confidence and immature defenses and symptoms of hostility were found. Nevertheless, a greater number of scenes in lucid dreams were accompanied by more frequent experience of phobic symptoms (Table 3 ).

Whether they preceded or followed the onset of lucidity in dream, positive emotions were significantly associated with more frequent use of mature defenses. Furthermore, negative emotions were accompanied by more frequent use of immature and neurotic defenses and were also associated with all examined symptoms except hostility. Exceptions to the above were an insignificant association between negative emotions before the onset of lucidity with immature and neurotic defenses, as well as symptoms of paranoia and psychoticism. Negative associations of positive emotions with certain symptoms were also found, e.g. with phobia with regard to emotions before lucidity and with somatization, anxiety, paranoia and psychoticism when it comes to emotions following lucidity in sleep (Table 3).

Regarding lucidity induction techniques, correlation analyzes indicate that more frequent reality checking is accompanied by experiencing higher levels of all examined symptoms except hostility. The same was found for pre-sleep thoughts and obsessive-compulsiveness, anxiety and psychoticism; advanced techniques and somatization; alternation of sleep and wakefulness and paranoidity. However, according to the obtained results, more frequent reading about lucid dreams implied a lower level of use of neurotic defenses (Table 3). 
TABLICA 3. Povezanost različitih dimenzija lucidnih snova s tri skupine obrambenih mehanizama i devet vrsta psihopatoloških simptoma

TABLE 3. Association of different dimensions of lucid dreams with three groups of defense mechanisms and nine types of psychopathological symptoms

\begin{tabular}{|c|c|c|c|c|c|c|c|c|c|c|c|c|}
\hline & $\mathbf{z}$ & NR & NZ & $\mathbf{s}$ & OK & o & D & A & $\mathbf{N}$ & $\mathbf{F}$ & $\mathbf{P}$ & PH \\
\hline Frekvencija / Frequency & 0,05 & $-0,03$ & 0,09 & $0,15^{*}$ & $0,19^{* *}$ & 0,07 & $0,17^{* *}$ & 0,12 & 0,03 & 0,05 & 0,12 & 0,13 \\
\hline Trenutna / Momentary & 0,05 & 0,01 & 0,09 & $0,13^{*}$ & $0,16^{*}$ & 0,04 & 0,10 & 0,12 & 0,01 & 0,02 & 0,05 & 0,09 \\
\hline Produžena / Prolonged & 0,04 & $-0,03$ & 0,06 & $0,15^{*}$ & $0,15^{*}$ & 0,10 & $0,17^{* *}$ & $0,14^{*}$ & $-0,01$ & 0,10 & 0,11 & 0,13 \\
\hline Spontana / Spontaneous & $0,15^{*}$ & 0,03 & $0,13^{*}$ & 0,08 & $0,19^{* *}$ & 0,04 & $0,15^{*}$ & 0,09 & $-0,01$ & $-0,02$ & 0,06 & 0,09 \\
\hline Pokušaji / Attempts & 0,01 & $-0,05$ & 0,06 & 0,07 & 0,08 & $-0,00$ & 0,09 & 0,03 & 0,06 & 0,01 & 0,08 & 0,06 \\
\hline Uspjeh / Success & $-0,04$ & $-0,07$ & $-0,00$ & $0,13^{*}$ & $0,15^{*}$ & 0,11 & $0,13^{*}$ & 0,11 & 0,04 & 0,09 & $0,15^{*}$ & 0,11 \\
\hline Intenzitet / Intensity & 0,04 & $-0,12$ & $-0,14^{*}$ & $-0,05$ & $-0,04$ & $-0,05$ & $-0,00$ & $-0,02$ & $-0,14^{*}$ & 0,04 & $-0,10$ & $-0,05$ \\
\hline Sigurnost / Confidence & 0,07 & $-0,09$ & $-0,15^{*}$ & $-0,05$ & $-0,12$ & $-0,10$ & $-0,04$ & $-0,04$ & $-0,14^{*}$ & $-0,05$ & $-0,12$ & $-0,10$ \\
\hline Aktivnost / Activity & 0,07 & $-0,15^{*}$ & $-0,08$ & $-0,12$ & $-0,09$ & $-0,09$ & $-0,07$ & $-0,10$ & $-0,09$ & $-0,03$ & $-0,13$ & $-0,09$ \\
\hline Kontrola / Control & 0,00 & $-0,12$ & $-0,13$ & $-0,09$ & $-0,04$ & $-0,06$ & $-0,02$ & $-0,06$ & $-0,08$ & $-0,04$ & $-0,07$ & $-0,03$ \\
\hline Trajanje / Length & 0,01 & $-0,03$ & $-0,08$ & 0,04 & 0,04 & 0,04 & 0,07 & 0,04 & $-0,10$ & 0,12 & $-0,04$ & 0,01 \\
\hline Scene / Scenes & $-0,04$ & $-0,04$ & $-0,08$ & 0,07 & 0,09 & 0,04 & 0,06 & 0,09 & $-0,09$ & $0,16^{* *}$ & $-0,01$ & 0,02 \\
\hline Emocije prije / Emotions before & $0,16^{* *}$ & $-0,10$ & $-0,08$ & $-0,15^{* *}$ & $-0,14^{*}$ & $-0,16^{* *}$ & $-0,13^{*}$ & $-0,14^{*}$ & $-0,08$ & $-0,22^{* *}$ & $-0,14^{*}$ & $-0,14^{*}$ \\
\hline Pozitivne / Positive & $0,18^{* *}$ & $-0,09$ & $-0,09$ & $-0,09$ & $-0,11$ & $-0,13$ & $-0,10$ & $-0,10$ & $-0,06$ & $-0,16^{* *}$ & $-0,12$ & $-0,13$ \\
\hline Negativne / Negative & $-0,12$ & 0,09 & 0,07 & $0,19^{* *}$ & $0,14^{*}$ & $0,17^{* *}$ & $0,14^{*}$ & $0,16^{* *}$ & 0,09 & $0,24^{* *}$ & 0,13 & 0,13 \\
\hline Emocije nakon / Emotions after & $0,19^{* *}$ & $-0,07$ & $-0,08$ & $-0,20^{*}$ & $-0,13$ & $-0,25^{* *}$ & $-0,19^{* *}$ & $-0,19^{* *}$ & $-0,07$ & $-0,19^{* *}$ & $-0,18^{* *}$ & $-0,17^{* *}$ \\
\hline Pozitivne / Positive & $0,24^{* *}$ & 0,02 & $-0,01$ & $-0,15^{* *}$ & $-0,06$ & $-0,21$ & $-0,13$ & $-0,16^{* *}$ & $-0,04$ & $-0,13$ & $-0,15^{* *}$ & $-0,16^{* *}$ \\
\hline Negativne / Negative & $-0,11$ & $0,14^{*}$ & $0,13^{*}$ & $0,21^{* *}$ & $0,16^{*}$ & $0,25^{* *}$ & $0,21^{* *}$ & $0,20^{* *}$ & 0,08 & $0,22^{* *}$ & $0,18^{* *}$ & $0,16^{*}$ \\
\hline Tehnike / Techniques & $-0,02$ & $-0,02$ & 0,02 & 0,10 & 0,13 & 0,09 & 0,05 & 0,08 & 0,04 & 0,12 & $0,13^{*}$ & 0,13 \\
\hline Dnevnik spavanja / Dream diary & 0,05 & 0,02 & $-0,01$ & $-0,07$ & $-0,06$ & $-0,05$ & $-0,08$ & $-0,06$ & $-0,11$ & 0,03 & $-0,08$ & $-0,02$ \\
\hline Čitanje / Reading & $-0,08$ & $-0,14^{*}$ & $-0,10$ & 0,02 & 0,10 & $-0,00$ & $-0,03$ & $-0,02$ & $-0,02$ & 0,01 & 0,08 & 0,06 \\
\hline Dnevne misli / Daily thoughts & $-0,01$ & $-0,03$ & 0,02 & 0,04 & 0,06 & 0,03 & $-0,01$ & 0,01 & $-0,01$ & 0,03 & 0,06 & 0,05 \\
\hline Provjera stvarnosti / Reality checks & 0,02 & 0,07 & 0,09 & $0,21^{* *}$ & $0,15^{*}$ & $0,15^{*}$ & $0,15^{*}$ & $0,17^{* *}$ & 0,10 & $0,20^{* *}$ & $0,17^{* *}$ & $0,15^{*}$ \\
\hline Planiranje spavanja / Planning sleep time & $-0,03$ & 0,03 & 0,08 & 0,06 & 0,10 & 0,13 & 0,00 & 0,07 & 0,06 & 0,10 & $0,19^{* *}$ & 0,07 \\
\hline Napredne tehnike / Advanced techniques & $-0,04$ & $-0,05$ & 0,00 & $0,14^{*}$ & 0,07 & 0,02 & 0,06 & 0,06 & 0,06 & 0,04 & 0,09 & 0,10 \\
\hline Prije sna misli / Thoughts at bedtime & $-0,02$ & $-0,02$ & $-0,02$ & 0,07 & $0,16^{*}$ & 0,10 & 0,12 & $0,14^{*}$ & 0,10 & 0,09 & 0,10 & $0,18^{* *}$ \\
\hline Želja / Desire & $0,23^{* *}$ & $-0,04$ & $-0,00$ & $-0,14^{*}$ & $-0,02$ & $-0,16^{*}$ & $-0,05$ & $-0,18^{* *}$ & $-0,03$ & $-0,16^{*}$ & $-0,09$ & $-0,09$ \\
\hline Radnja / Plot & 0,03 & 0,10 & 0,06 & $-0,04$ & 0,03 & $-0,07$ & $-0,00$ & $-0,02$ & $-0,10$ & $-0,03$ & $-0,04$ & 0,03 \\
\hline Sjećanje / Recall & $-0,03$ & $-0,00$ & 0,02 & 0,03 & 0,02 & 0,07 & 0,10 & 0,04 & 0,08 & 0,03 & 0,06 & 0,06 \\
\hline Buđenja / Awakenings & $-0,13^{*}$ & 0,03 & 0,06 & $0,19^{* *}$ & $0,18^{* *}$ & $0,18^{* *}$ & $0,18^{* *}$ & $0,21^{* *}$ & $0,15^{*}$ & $0,22^{* *}$ & 0,10 & $0,15^{*}$ \\
\hline Kvaliteta / Quality & 0,09 & $-0,10$ & $-0,26^{* *}$ & $-0,27^{* *}$ & $-0,30^{* *} \quad, \quad, \quad$ & $-0,23^{* *}, \quad>$ & $-0,26^{* *}$ & $-0,18^{* *}$ & $-0,25^{* *}$ & $-0,21^{* *}$ & $-0,24^{* *}$ & $-0,27^{* *}$ \\
\hline
\end{tabular}

Legenda / Legend : ${ }^{p} p<0,05{ }^{* *} p<0,01$ Z-zreli / mature, NR-neurotski / neurotic, NZ-nezreli / immature, S-somatizacija / somatization, OK-opsesivna kompulzivnost / obsessive compulsiveness, O-osjetljivost / sensitivity, D-depresija / depression, A-anksioznost / anxiety, N-neprijateljstvo / hostility, F-fobičnost / phobia, P-paranoidnost / paranoid, PH-psihoticizam / psychoticism

sna i opsesivnu kompulzivnost, anksioznost i psihoticizam; napredne tehnike i somatizaciju te izmjenu spavanja i budnosti i paranoidnost. Ipak, prema dobivenim rezultatima češće či-
Finally, higher desire for a new lucid dream was accompanied by more frequent use of mature defenses and less frequent experiences of somatization, sensitivity, anxiety and phobia symptoms. 
tanje o lucidnim snovima podrazumijeva nižu razinu neurotskih obrana (tablica 3.).

Konačno, veća želja za ponovnim lucidnim snom popraćena je češćim zrelim obranama te rjeđim doživljavanjem somatizacije, osjetljivosti, anksioznosti i fobičnosti. Češća su buđenja povezana s rjeđim korištenjem zrelih obrana te višim razinama svih simptoma osim paranoidnosti. Kada je riječ o kvaliteti spavanja, dobiveni rezultati pokazuju negativne povezanosti s nezrelim obranama i svim ispitanim simptomima (tablica 3.).

\section{RASPRAVA}

S obzirom na manjak istraživanja lucidnih snova javila se potreba za validacijom upitnika lucidnosti na hrvatskom uzorku. Prema dosadašnjim istraživanjima, svaki drugi student doživio je barem jedan lucidni san tijekom života (41). Utvrđena odstupanja od normalne distribucije vezana za induktivnu lucidnost već su prethodno potvrđena (21). Ovaj je fenomen, posebno kad je izazvan, sam po sebi rijedak. Ipak, postotak sudionika koji nikada ili rijetko izaziva lucidnost manji je od onog dobivenog $\mathrm{u}$ originalnom radu (21). Koeficijenti pouzdanosti podljestvica upitnika, kao i povezanosti rezultata postignutih na pojedinim podljestvicama uglavnom su u skladu s polazišnim istraživanjem (21). Originalni FILD upitnik uključuje pet podljestvica (21). Premda njegove autorice, kao što je prethodno i rečeno, nisu provjeravale faktorsku strukturu upitnika, u ovom je istraživanju navedeno bilo moguće provesti zbog brojnijeg i heterogenijeg uzorka. Dobiveni su rezultati pokazali četvero-faktorsku soluciju, u kojoj su čestice vezane uz emocije prije i nakon lucidnosti formirale jedan jedinstveni faktor, umjesto dva faktora koja su bila očekivana s obzirom na polazišno istraživanje (21). Ovakvi rezultati dodatno ističu emocionalnost kao bitnu dimenziju lucidnosti. Ovo je korak unaprijed u odnosu na dosadašnje spoznaje o višedi-
More frequent awakenings were associated with 107 less frequent use of mature defenses and higher levels of all symptoms except paranoia. With regard to sleep quality, the results showed negative associations with immature defenses and all tested symptoms (Table 3).

\section{DISCUSSION}

Considering the lack of research on lucid dreams, there was a need to validate the lucidity questionnaire on a Croatian population sample. According to previous studies, every second student has experienced at least one lucid dream in their lifetime (41). The deviations from the normal distribution related to inductive lucidity identified in the present study have already been previously confirmed (21). This phenomenon, especially when induced, is very rare. Nevertheless, the percentage of participants who never or rarely induce lucidity in dreams is lower than obtained in the original paper (21). These results indicate that our participants are quite familiar with inductive lucidity. The reliability coefficients of the subscales of the questionnaire, as well as the correlation of the results achieved on individual subscales, are generally in line with the initial research (21). The original FILD questionnaire includes five subscales (21). Although its authors, as previously stated, did not test the factor structure of the questionnaire, in the present study it was possible to do so due to a more numerous and heterogeneous sample. The obtained results showed a four-factor solution, in which the emotion-related items before and after lucidity formed a single factor, instead of the two factors that were expected with respect to the baseline study (21). Such results further emphasize emotionality as an essential dimension of lucidity. This is a step forward compared to previous knowledge of the multidimensionality of this construct, which assumes the separation of frequency from intensity of lucid dreams (21). Minor inconsistencies of the obtained results with those reported previously (21) can be ex- 
menzionalnosti ovog konstrukta, koje pretpostavljaju razdvajanje frekvencije od intenziteta lucidnosti (21). Manje nesukladnosti dobivenih rezultata s postojećim (21) moguće je objasniti metodološkim razlikama koje se odnose na heterogenost i veličine uzoraka. U provedenom istraživanju sudjelovao je heterogeniji uzorak mlađe odrasle dobi $(\mathrm{N}=665)$, a valjanost upitnika provjerena je na temelju rezultata 231 sudionika. S druge strane, brojčano manji i homogeniji uzorak studenata $(\mathrm{N}=142) \mathrm{u}$ istraživanju (21) nije omogućio provjeru faktorske strukture originalnog FILD upitnika (21).

Dobiveni rezultati ukazuju da je lucidnost povezana sa distresom samo kada je realizirana, što nije u potpunosti nesukladno dosadašnjim nalazima (21) o maladaptivnosti indukcije lucidnosti. Moguće je da samo visoko učestala indukcija može postati uspješna u doživljaju lucidnog sna, s cijenom na psihopatološkom planu, dok mu rijetka i nedosljedna primjena indukcije ne odmaže ni pridonosi. Pozitivni odnosi zrelih, ali i nezrelih obrana sa spontanom lucidnosti, anksioznosti s produženom lucidnosti, kao i paranoidnosti s uspješno izazvanom lucidnosti također pružaju bitne implikacije, koje bi trebalo provjeriti u daljnjim istraživanjima. Vezano uz intenzitet lucidnosti, negativni odnosi sigurnosti sa simptomima neprijateljstva i nezrelim obranama te aktivnosti s neurotskim obranama obećavajući su nalazi. Ipak, veći broj scena u radnji sna povezan je s češćim simptomima fobičnosti. Poznato je da je dinamičnost sustava obrana prediktivna za razne psihopatološke ishode, no tek kao krajnji rezultat, s vremenskim odmakom (33). Potencijalni doprinos intenziteta lucidnosti u smanjenju psihopatoloških simptoma trebalo bi provjeriti longitudinalnim istraživanjem.

Provedeno istraživanje pokazuje da je emocionalnost vezana uz lucidnost najznačajniji korelat psihopatološkog distresa. Dok je značajna i najveća povezanost dobivena sa simptomima fobičnosti, čija je glavna karakteristika upravo plained by methodological differences comprising the heterogeneity and sample sizes. A more heterogeneous sample of young adults $(\mathrm{N}=665)$ participated in this study, and the validity of the questionnaire was verified based on the results of 231 participants. On the other hand, a numerically smaller and more homogeneous sample of students ( $\mathrm{N}=142)$ in the previous study (21) did not allow verification of the factor structure of the original FILD questionnaire (21).

The obtained results indicate that lucidity is associated with distress only when it is achieved, which is not completely inconsistent with previous findings (21) on the maladaptiveness of lucidity induction. It is possible that only highly frequent induction can become successful in achieving lucid dreams, with a price on a psychopathological level, while infrequent and inconsistent application of induction neither helps nor hinders. The positive relationship of mature but also immature defenses with spontaneous lucidity, anxiety with prolonged lucidity and paranoia with successfully induced lucidity also lead to important implications, which should be verified in further research. Regarding the intensity of lucidity, the negative relationships of confidence in lucidity with symptoms of hostility and use of immature defenses as well as of activity with use of neurotic defenses are promising findings. Still, a greater number of scenes in the action of the dream were associated with more frequent symptoms of phobia. It is known that the dynamism of the defense system is predictive of various psychopathological outcomes, but only as an end result with a time lag (33). The potential contribution of lucidity intensity in reducing psychopathological symptoms should be examined by longitudinal research.

The present study shows that emotionality related to lucidity is the most important correlate of psychopathological distress. While the significant and greatest association was found with phobic symptoms, the main characteristic of which is precisely the excessive irrational emotionality associated with the object of fear (39), hostility is the only psychopathological symptom that was 
pretjerana iracionalna emocionalnost povezana s objektom straha (39), neprijateljstvo je jedini psihopatološki simptom koji nije bio značajno povezan s emocionalnošću u ovom istraživanju. Moguće je da u iskustvu lucidnosti nema mjesta hostilnim ni njima suprotnim osjećajima. Većina lucidnih sanjača o tom iskustvu govori u smislu smirenosti, samorefleksije, usredotočene svijesti, uvida te otvorenosti k iskustvima $(17,19,42)$, odnosno blago pozitivnih do izrazito neutralnih emocionalnih stanja. Izgledno je i da je etiologija simptoma više vezana uz emocije koje slijede lucidnost u snu, nego uz one koje joj prethode. Takve emocije, pritom negativne, prati i češća uporaba nezrelih i neurotskih obrana. Nadalje, tehnika misli prije sna pozitivan je korelat simptoma opsesivne-kompulzivnosti, anksioznosti i psihoticizma. Isto vrijedi za odnose izmjene budnosti i spavanja s paranoidnosti te naprednih tehnika sa somatizacijom. Međutim, od svih tehnika najveći je oprez nužno preusmjeriti na provjeru stvarnosti, čijim se izvođenjem brišu granice budnosti i spavanja, stvarnosti i mašte (21). Ipak, negativan odnos čitanja o lucidnosti s neurotskim obranama implicira da nisu sve tehnike indukcije maladaptivne. Od dodatnih varijabli koje su obuhvaćene ovim istraživanjem, kao glavni negativni korelati psihopatološkog distresa izdvojili su se želja za novim lucidnim snom te kvaliteta spavanja, dok se broj buđenja pokazao pozitivnim korelatom. Sukladno hipotezi kontinuiteta, prethodno navedeni nalazi ukazuju na dominantnu ulogu negativnih emocija nakon lucidnosti u snovima, broja buđenja, induktivne lucidnosti te frekvencije lucidnosti kao potencijalno rizičnih, a kvalitete spavanja, želje za novim lucidnim snom, intenziteta lucidnosti i pozitivnih emocija kao zaštitnih faktora psihološkog zdravlja. Međutim, za opravdanost ovakvih tvrdnji važno je provesti statističke analize koje omogućavaju zaključke o kauzalnim odnosima.

Postoje neka ograničenja, kao i prijedlozi za buduće istraživače. Prvo, nužno je razjasniti not significantly associated with emotionality in 109 this study. It is possible that there is no place for hostile or opposing feelings in the experience of lucidity. Most lucid dreamers describe this experience in terms of calmness, self-reflection, focused awareness, insight and openness to experiences $(17,19,42)$, i.e. in terms of mildly positive to extremely neutral emotional states. It is also likely that the etiology of symptoms is more related to the emotions that follow lucidity in sleep than to those that precede it. Such emotions, especially when negative, are accompanied by more frequent use of immature and neurotic defenses. Furthermore, the pre-sleep thought technique is a positive correlate of the symptoms of obsessive-compulsiveness, anxiety and psychoticism. The same has been confirmed for the relationship between alternation of wakefulness and sleep and paranoia, and advanced techniques with somatization. However, of all the techniques, the greatest caution must be directed towards the verification of reality, which erases the boundaries of wakefulness and sleep, reality and imagination (21). Nevertheless, the negative relationship of reading about lucidity with neurotic defenses implies that not all induction techniques are maladaptive. Of the additional variables included in this study, the main negative correlates of psychopathological distress were the desire for a new lucid dream and sleep quality, while the number of awakenings proved to be a positive correlate. According to the continuity hypothesis, the above findings indicate the dominant role of negative emotions after lucidity in dreams, number of awakenings, inductive lucidity and frequency of lucidity as potentially risky, and sleep quality, desire for a new lucid dream, lucidity intensity and positive emotions as protective factors of psychological health. However, to justify of such claims it is important to conduct statistical analyzes that demonstrate conclusions about causal relations between these factors.

There were some limitations to are study as well as suggestions for future researchers. First, it is necessary to clarify whether lucidity is better thought of in terms of one type of dream and its 
je li o lucidnosti opravdanije govoriti u smislu jedne vrste snova te s njima povezanim konstruktima poput obrambenih mehanizama ili u terminima zasebnog entiteta povišene svijesti, koji bi strategije suočavanja, kao svjesni oblici emocionalne regulacije, mogle bolje objasniti. Drugo, istraživanje je provedeno početkom prvog vala COVID-19 pandemije u RH te potresa u Zagrebu, što pogoduje mogućoj kontaminiranosti rezultata na mjerama psihopatoloških simptoma. Treće, mjere fizičkog distanciranja rezultirale su online provođenjem istraživanja, a kontrola pristranosti i reprezentativnosti uzorka nastojala se osigurati na način da je poziv za sudjelovanje u ovom istraživanju objavljen u tematski raznolikim Facebook grupama. Četvrto, prirodnu je lucidnost izazovno istraživati zbog njene nedovoljno visoke učestalosti. Raspon istraživačkih metoda za prikupljanje podataka o induktivnoj lucidnosti vrlo je širok, npr. vođenjem dnevnika spavanja, no postojeći podatci (21) upućuju na negativne trendove u mentalnom zdravlju tijekom ovakvih aktivnosti. Kako psihološka dobrobit sudionika ne bi bila upitna, nacrt ovog istraživanja bio je kros-sekvencionalni, nauštrb njegovim nedostatcima kao retrospektivnoj mjeri. Iskustvo lucidnosti u snu jedinstven je doživljaj koji je samim time distinktivno iskustvo pri spavanju. Stoga, pretpostavilo se da sposobnost dosjećanja nije toliko narušena te da ipak osigurava dovoljno informacija od trenutnog istraživačkog interesa, a da pri tome udaljuje ovo istraživanje od potencijalno socijalno osjetljivog.

\section{ZAKLJUČCI}

Primijenjeni FILD upitnik pokazao je zadovoljavajuće psihometrijske karakteristike na hrvatskom uzorku. Prema dobivenim rezultatima, negativne emocije, broj buđenja, tehnike indukcije te frekvencija lucidnosti pokazali su se značajnim i pozitivnim korelatima, a kvaliteta spavanja, želja za novim lucidnim snom, pozitivne associated constructs, such as defense mechanisms, or in terms of a separate entity of heightened consciousness, which coping strategies, such as conscious forms of emotional regulation, could explain better. Second, the study was conducted at the beginning of the first wave of the COVID-19 pandemic in the Republic of Croatia and the earthquake in Zagreb, which favors possible contamination of the results on measures of psychopathological symptoms. Third, physical distancing measures resulted in online conduct of the survey, although control of the bias and representativeness of the sample was used to to ensure that the invitation to participate in this survey was published in thematically diverse Facebook groups. Fourth, spontaneous lucidity is challenging to investigate due to its insufficiently high incidence in the population. The range of research methods for collecting data on inductive lucidity is very wide, e.g., keeping a sleep diary, but existing literature (21) suggests negative trends in mental health during such activities. In order not to question the psychological well-being of the participants, the draft of this research was cross-sequential, to the detriment of its shortcomings as a retrospective measure. The experience of lucidity in sleep is a unique mental event that is thus a distinctive experience when sleeping. Therefore, it was assumed that the ability to remember is not so impaired and that it still provides enough information of current research interest, while distancing this study from what may be potentially socially sensitive.

\section{CONCLUSIONS}

The applied FILD questionnaire showed satisfactory psychometric characteristics in the Croatian population sample. According to the obtained results, negative emotions, number of awakenings, induction techniques and lucidity frequency proved to be significant and positive correlates, and sleep quality, desire for a new lucid dream, positive emotions and lucidity intensity were negative correlates of psycho- 
emocije te intenzitet lucidnosti negativnim korelatima psihopatoloških simptoma. Ovakvi rezultati, jednako kao i dobivene povezanosti obrambenih mehanizama s različitim dimenzijama lucidnosti, sukladni su hipotezi kontinuiteta. Rezultati impliciraju da su, pored kvalitete spavanja, broja buđenja i želje za novim lucidnim snom, tehnike indukcije i emocionalnost povezane s lucidnošću u snovima dominantne odrednice psihološke dobrobiti lucidnih sanjača. pathological symptoms. Such results, as well as the association of defense mechanisms with different dimensions of lucidity, are consistent with the continuity hypothesis. The results imply that, in addition to sleep quality, number of awakenings and desire for a new lucid dream, induction techniques and emotionality associated with lucidity in dreams are dominant determinants of the psychological well-being of lucid dreamers.

\section{LITERATURA / REFERENCES}

1. Freud S. Interpretation of dreams. In: Strachey J. (ed.) The Standard Edition of the Complete Works of Sigmund Freud (4-5). Hogarth Press, 1899.

2. Voss U, D'Agostino A, Kolibius L, Klimke A, Scarone S, Hobson A. Insight and Dissociation in Lucid Dreaming and Psychosis. Front Psychol 2018; 9: 21-64. Preuzeto 29.3.2021 https://doi.org/10.3389/fpsyg.2018.02164.

3. Hobson A, Voss U. A mind to go out of: reflections on primary and secondary consciousness. Conscious Cogn 2011; 2: 993-997. Preuzeto 29.3.2021. https://doi.org/10.1016/j.concog.2010.09.018.

4. Soffer-Dudek N. Arousal in Nocturnal Consciousness: How Dream- and Sleep- Experiences May Inform Us of Poor Sleep Quality, Stress, and Psychopathology. Front Psychol 2017; 8: 733. Preuzeto 29.3.2021. https://doi.org/10.3389/ fpsyg.2017.00733.

5. Watson D. Dissociations of the night: Individual differences in sleep-related experiences and their relation to dissociation and schizotypy. J Abnorm Psychol 2001; 11: 526-35. Preuzeto 29.3.2021. https://doi.org/10.1037/0021-843X.110.4.526.

6. Osho. The book of secrets: 112 keys to the mystery within: a comprehensive guide to meditation techniques described in the Vigyan Bhairav Tantra. New York: St. Martin's Griffin, 1974.

7. Van Eeden F. A study of dreams. Proceedings of the Society for Psychical Research 1913; 26: 431-61.

8. Hervey de Saint-Denis L. Dreams and How to Guide Them. London: Duckworth, 1982.

9. Sparrow G. Lucid dreaming: Dawning of the clear light. Virginia Beach, VA: A.R.E. Press, 1976.

10. Hearne KMT. Lucid-dreams: an electrophysiological and psychological study. PhD Thesis. Liverpool: University of Liverpool, 1978.

11. LaBerge S, Nagel L, Dement WC, Zarcone V Jr. Lucid dreaming verified by volitional communication during REM sleep. Percept Mot Skills 1981; 52: 727-732. Preuzeto 29.3.2021. https://doi.org/10.2466\%2Fpms.1981.52.3.727.

12. Voss U, Holzmann R, Hobson A, Paulus W, Koppehele-Gossel J, Klimke A et al. Induction of self-awareness in dreams through frontal low current stimulation of gamma activity. Nat Neurosci 2014; 17(6): 810-812. Preuzeto 29.3.2021. https:// doi.org/10.1038/nn.3719.

13. Stumbrys T, Erlacher D, Johnson M, Schredl M. The phenomenology of lucid dreaming: an online survey. Am J Psychol 2014; 127: 191-204.

14. Voss U, Schermelleh-Engel K, Windt J, Frenzel C, Hobson A. Measuring consciousness in dreams: the lucidity and consciousness in dreams scale. Conscious Cogn 2013; 22: 8-21. Preuzeto 29.3.2021. https://doi.org/10.1038/nn.3719.

15. Erlacher D, SchredI M. Practicing a motor task in a lucid dream enhances subsequent performance: A pilot study. The Sport Psychologist 2010; 24(2): 157-67.

16. Saunders DT, Roe CA, Smith G, Clegg H. Lucid dreaming incidence: A quality effects meta-analysis of 50 years of research. Conscious Cogn 2016; 43: 197-215. Preuzeto 29.3.2021. https://doi.org/10.1016/j.concog.2016.06.002.

17. Rosenbusch KM. Lucid Dreaming: Exploring the Effects of Lucidity within Dreams on Emotion Regulation, Positive Emotions, Interoceptive Awareness, and Mindfulness. Diplomski rad. Arizona State University, 2016.

18. Stumbrys T. Bridging lucid dreaming research and transpersonal psychology: Toward transpersonal studies of lucid dreams. J Transpersonal Psychol 2018; 50(2): 176-193.

19. Schredl M, Erlacher D. Lucid dreaming frequency and personality. Pers Individ Dif 2004; 37: 1463-1473. Preuzeto 29.3.2021. https://doi.org/10.1177\%2F0276236616648653.

20. Alvarado CS, Zingrone NL. Interrelationships of parapsychological experiences, dream recall, and lucid dreams in a survey with predominantly Spanish participants. Imagin Cogn Pers 2007; 27: 63-69. Preuzeto 29.3.2021. https://doi.org/10.2190\%2FIC.27.1.f.

21. Aviram L, Soffer-Dudek N. Lucid Dreaming: Intensity, But Not Frequency, Is Inversely Related to Psychopathology. Front Psychol. 2018; 9: 384. Preuzeto 29.3.2021. https://doi.org/10.3389/fpsyg.2018.00384.

22. Taitz IY. Learning lucid dreaming and its effect on depression inundergraduates. Int J Dream Res 2011; 4: 117-26. Preuzeto 29.3.2021. https://doi.org/10.11588/ijodr.2011.2.9123. 
23. Soffer-Dudek N, Shahar G. Daily stress interacts with trait dissociation to predict sleep-related experiences in young adults. J Abnorm Psychol 2011; 12: 719-29. Preuzeto 29.3.2021. https://doi.org/10.1037/a0022941.

24. Harb GC, Brownlow JA, Ross RJ. Posttraumatic nightmares and imagery rehearsal: the possible role of lucid dreaming. Dreaming 2016; 26: 238-49. Preuzeto 29.3.2021. https://doi.org/10.1037/drm0000030.

25. Van Heugten-van der Kloet D, Merckelbach H, Giesbrecht T, Broers N. Night-time experiences and daytime dissociation: a path analysis modeling study. Psychiatry Res 2014; 216: 236-41. Preuzeto 29.3.2021. https://doi.org/10.1016/j. psychres.2013.12.053.

26. Soffer-Dudek N, Shahar G. What are sleep-related experiences? Associations with transliminality, psychological distress, and life stress. Conscious Cogn 2009; 18: 891-904. Preuzeto 29.3.2021. https://doi.org/10.1016/j.concog.2008.07.007.

27. Knox J, Lynn SJ. Sleep experiences, dissociation, imaginal experiences, and schizotypy: the role of context. Conscious Cogn 2014; 23: 22-31. Preuzeto 29.3.2021. https://psycnet.apa.org/doi/10.1016/j.concog.2013.10.007.

28. Soffer-Dudek N, Sadeh A. Dream recall frequency and unusual dream experiences in early adolescence: Longitudinal links to behavior problems. J Res Adolesc 2013; 23: 635-51.Preuzeto 29.3.2021. https://doi.org/10.1111/jora.12007.

29. Stumbrys T, Erlacher D. Applications of lucid dreams and their effects on the mood upon awakening. Int J Dream Res 2016; 9(2): 146-50. Preuzeto 29.3.2021. https://doi.org/10.11588/ijodr.2016.2.33114.

30. LaBerge S. Lucid dreaming: paradoxes of dreaming consciousness. In: Cardeña EE, Lynn SJE, Krippner SE (ed.) Varieties of Anomalous Experience: Examining the Scientific Evidence. Washington, DC: AmericanPsychological Association. 2014; 145-73. Preuzeto 29.3.2021. http://dx.doi.org/10.1037/14258-006.

31. Doll E, Gittler G, Holzinger B. Dreaming, lucid dreaming and personality. Int J Dream Res 2009; 2: 52-57. Preuzeto 29.3.2021. https://doi.org/10.11588/ijodr.2009.2.142.

32. Freud S. The Interpretation of Dreams. London: Oxford University Press, 1990.

33. Vaillant GE. Adaptive mental mechanisms: Their role in a positive psychology. Am Psychol 2000; 55: 89-98. Preuzeto 29.3.2021. https://doi.apa.org/doi/10.1037/0003-066X.55.1.89.

34. Cramer P. Understanding defense mechanisms. Psychodyn Psychiatry 2015; 43: 523-52. Preuzeto 29.3.2021. https://doi. org/10.1521/pdps.2015.43.4.523.

35. Yu CKC. The mechanisms of defense and dreaming. Dreaming 2011; 21: 51-69. Preuzeto 29.3.2021.https://www.researchgate.net/deref/http\%3A\%2F\%2Fdx.doi.org\%2F10.1037\%2Fa0022867.

36. Hall CS, Nordby VJ. The Individual and His Dreams. New York: New American Library, 1972.

37. Andrews G, Singh M, Bond M. The Defence Style Questionnaire. J Nerv Ment Dis. 1993; 181: 246-56.

38. Vulić-Prtorić A. Psihometrijska validacija Upitnika obrambenih stilova DSQ-40 -preliminarno istraživanje. Soc psihijat 2008; 36 (2): 49-57.

39. Derogatis LR. Brief Symptom Inventory (BSI) - Administration, scoring and procedures manual. Minneapolis: NCS Pearson INC, 1993.

40. Štibrić M. Psihometrijska validacija Derogatisovog Kratkog inventara simptoma. Neobjavljeni diplomski rad. Zagreb: Odsjek za psihologiju Filozofskog fakulteta Sveučilišta u Zagrebu, 2005.

41. Tkalčić M, Lončarić D. Značajke spavanja i sanjanja studenata psihologije. Psihologijske teme 1997; 6(7): 105-14.

42. Carhart-Harris RL, Leech R, Hellyer PJ, Shanahan M, Feilding A, Tagliazucchi E et al. The entropic brain: a theory of conscious states informed by neuroimaging research with psychedelic drugs. Front Hum Neurosci 2014; 8-20. Preuzeto 29.3.2021. https://doi.org/10.3389/fnhum.2014.00020. 